\title{
Determination of stand structure in even-aged Oriental Beech Forests in Turkey
}

\author{
Determinación de la estructura de rodales de Fagus orientalis coetáneos en Turquía
}

\author{
Aydın Kahriman ${ }^{\text {a*, Lokman Altun }}{ }^{\mathrm{b}}$, Engin Güvendi ${ }^{\mathrm{c}}$

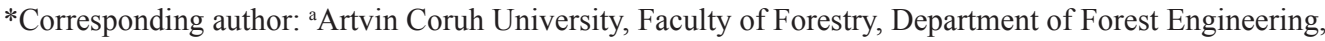 \\ 08000, Artvin, Turkey, phone+90-4662151035, fax+90-4662151035, kaydin61@hotmail.com \\ ${ }^{\mathrm{b}}$ Karadeniz Technical University, Faculty of Forestry, Trabzon, Turkey. \\ ${ }^{\mathrm{c}}$ Gümüşhane University, Kürtün Vocational School, Gümüşhane, Turkey.
}

\begin{abstract}
SUMMARY
This study aimed at developing a stand yield model for even-aged and pure Oriental beech (Fagus orientalis) stands in Sinop Province, located in the north of Turkey. The data used in this study were obtained from 238 sample plots. The sample plots are 24-131 years of stand age range, 19.0-35.9 m of site index range, and 2.2-10.8 of stand density range (relative density index). With the generated equation systems, stand age, site index and density of the three main factors in Oriental beech stands, including the effects of individual, dual and triple factor interactions on the stands were numerically determined. As for even-aged Oriental beech stands, the main stand volume values increase depending on age, site index and density. The number of stems per hectare decreases as the stand grows older, and site index rises; the number, however, increases in parallel with stand density. The current annual volume increment reaches a peak at 3035 years at all site index groups and density levels, and begins to fall afterwards. Mean annual volume increment peaks up at 65-75 years at all site index classes and density levels, before beginning to decline. The results were in arrangement with the acknowledged growth rules. Stand yield models were assessed as Density-Variable Yield Table used for estimation of the remaining, removal and total stands.
\end{abstract}

Key words: stand model, oriental beech, density-variable yield table, pure stand.

\section{RESUMEN}

Este estudio tuvo como objetivo desarrollar un modelo de rendimiento de rodales para bosques puros y uniforme de Fagus orientalis en la provincia de Sinop, norte de Turquía. Los datos se obtuvieron de 238 parcelas de muestreo de rodales con edad de 24-131 años, índice de sitio de 19,0-35,9 m e índice de densidad relativo de 2,2-10,8. Con sistemas de ecuaciones generadas fueron determinados numéricamente la edad del rodal, el índice de sitio y la densidad de los rodales, incluyendo la determinación numérica de los efectos de las interacciones de los factores individuales, dobles y triples. En los rodales coetáneos, el aumento principal de los valores dependió de la edad, el índice de sitio y la densidad. La cantidad de tallos por hectárea disminuyó a medida que el rodal envejecía y el índice de sitio aumentaba; la cantidad, sin embargo, aumentó en paralelo con la densidad del rodal. El incremento de volumen anual actual alcanzó un pico a los 30-35 años en todos los grupos de índice de sitio y de niveles de densidad, y comenzó a caer después. El incremento anual del volumen medio escala su pico a los 65-75 años en todas las clases de índice de sitio y niveles de densidad, antes de comenzar a disminuir. Los resultados se encontraron de acuerdo con las normas reconocidas de crecimiento. El modelo de rendimiento de rodales se evaluó como tabla de rendimiento de variable de densidad utilizada para la estimación de los rodales restantes, eliminados y totales.

Palabras clave: modelo de rodal, hayas orientales, tabla de rendimiento de variable de densidad, rodal puro.

\section{INTRODUCTION}

Growth and yield models have contributed to recruitment, growth and mortality models. Growth models are divided into three groups according to the information available for predictions: Stand Model, Size-Class Model and Individual-Tree Model (Vanclay 1994). Stand models provide forecast values of stand parameters such as number of trees per hectare, basal area, stand volume, quadratic mean diameter and mean height. Stand parameters determined by these models are average values; they do not provide predic- tions on the individual tree level (Pretzsch 2009). Size class models offer more detailed predictions than those offered by stand models about the structure of the stand and they use a class of trees as the basic unit for modelling (Vanclay 1994). The size class approach is a compromise between whole stand models and single-tree models. Individual tree models use individual trees as the basic unit for modelling and they offer more detailed predictions than predictions offered by stand models and size class models (Vanclay 1994).

The first yield studies regarding growth models were carried out 250 years ago, on even-aged pure stands. In the 
late $18^{\text {th }}$ and early $19^{\text {th }}$ century the earliest yield tables were established. They were a simple form of current examples. Pretzsch (2009) classifies development of growth models in four periods, namely, those in the form of a simple table with limited amount of data (from the last quarter of the $18^{\text {th }}$ century to the last quarter of the $19^{\text {th }}$ century), normal yield tables organized depending on the age and site index variables (from the last quarter of $19^{\text {th }}$ to the last quarter of $20^{\text {th }}$ century), yield models where growth relations are calculated via computer-aided mathematical equations (from the first quarter to the last quarter of the $20^{\text {th }}$ century) and much more detailed stand simulation models that can be hardly operated even in computers with high-speed memory (from the last quarter of the $20^{\text {th }}$ century up to the present).

Yield tables are divided into two groups: normal and variable density tables (Vanclay 1994). Normal yield tables can be established when the data are arranged according to age and site index; on the other hand, density-variable yield tables can be formed when the data are arranged depending on stand density, in addition to age and site index. Normal yield tables provide estimates of expected yield tabulated by stand age and site index for ideal, fully stocked or "normal" forest stands (Weiskittel et al. 2011). Growth significantly varies as a function of stand density, as well as depending on stand age and site index. Density-Variable Yield Tables provide mean values regarding age, site index and density of stand elements; thus, they enable the determination of change in growth of stands with varying density.

Fagus spp. is the most abundant and economically important hardwood genera in the temperate forests of the northern hemisphere (Sagheb-Talebi et al. 2011). There are 12 species under the beech genus; in Turkey, two of these grow naturally, namely, Oriental beech (Fagus orientalis Lipsky) and European Beech (Fagus sylvatica L.). Oriental beech is one of the principal forest tree species in economic terms in Turkey, covering a vast area. Oriental beech is naturally distributed in the Black Sea region, Aegean region, East Mediterranean and Marmara regions of Turkey, as well as in many other regions of the world (Davis 1982). According to the forest inventory conducted by the General Directorate of Forestry in 2012, the total area of forestlands in Turkey is equal to $22,342,935$ ha; of which, 7,346,831 ha (33\%) consist of forests of broadleaved trees, and beech forests constitute 1,961,660 ha (9\%) (General Directorate of Forestry 2015).

The yield tables developed in 1795 possibly represent the first serious approach to beech growth modeling (Álvarez-González et al. 2010). For the last 50 years, many yield tables and stand growth models have been developed for pure and natural beech stands in Europe (Dmitriev 1967, Carbonnier 1971, Marschall 1975, Mendlik 1983, Dittmar et al. 1986, Federal Agency of Forest Management of Russia 2008).

The first study about growth relationships of Oriental beech in Turkey was presented by Kalıpsiz (1962). In his study, he examined growth using data from single-tree and stand level. Alemdağ (1963) studied certain growth relations regarding Oriental beech in the Tokat basin, and recommended a rotation age of 120 years pursuant to the technical maturation period. Asan (1987) carried out site index studies on managed, even-aged, one stored, normal and medium-stocked ${ }^{1}$ stands that constitute more than $50 \%$ of Oriental beech in the Western and Central Black Sea regions. Carus (1998) made use of the site index table, as well as yield tables for normal and optimum formations, so as to put forth the development of Oriental beech in the Western and Central Black Sea regions, where these native species are the most widespread. In the study, normal yield tables revealed growth relations of normal density, even-aged and pure Oriental beech stands that are formed through natural ways without any intervention. Atic1 (1998), on the other hand, studied the growth of uneven-aged Oriental beech forests. He established site index, pressure, bark coefficient, periodical diameter increment and fine double-entry tree volume equation tables to be applied on beech forests of varying ages. Güvendi (2013) tried to determine absolute rotation ages on an ecological basis with regard to pure Oriental beech stands in the Sinop region. In the wake of his study, the absolute mean rotation age of pure Oriental beech forests in the lower zone was found to be 72-98 years, while the same was determined to be 90-102 years for those in the higher zone.

The objectives of this study are (i) to establish a Density-Variable Yield Table by means of stand models applicable for pure and even-aged Oriental beech stands within the Sinop region, (ii) to compare these yield table parameters with previous ones on Oriental beech in Turkey and on European beech and (iii) to make a general evaluation of beech growth in Sinop.

\section{METHODS}

This study employs, as research material, data from 238 sample plots of even-aged and pure Oriental beech stands in Sinop (Sinop, Ayancık and Türkeli Forest Enterprises), the northernmost city in Turkey (Altun et al. 2012) (figure 1). All of the 238 sample plots are in natural grown stands. This study area ranges in latitude (North) from $41^{\circ} 27^{\prime} 00^{\prime \prime}$ to $42^{\circ} 01^{\prime} 33^{\prime \prime}$ and in longitude (East) from $34^{\circ} 16^{\prime} 25^{\prime \prime}$ to $35^{\circ} 24^{\prime} 34^{\prime \prime}$. During selection of the mentioned sampling area, we tried to include as many representative areas as possible, where stands of Oriental beeches are fairly balanced in terms of different ages, site index and density levels.

The size of sampling areas in the hereby study varies between $400 \mathrm{~m}^{2}$ and $800 \mathrm{~m}^{2}$ depending on stand structure. In each sample area, diameter at breast height of each tree $\left(d_{1.30}\right)$ was measured, as well as height and age of a certain

Medium stocked: crown closure or canopy closure $=40-70 \%$; normal crown closure $\geq 70 \%$; especially close $=100 \%$. 


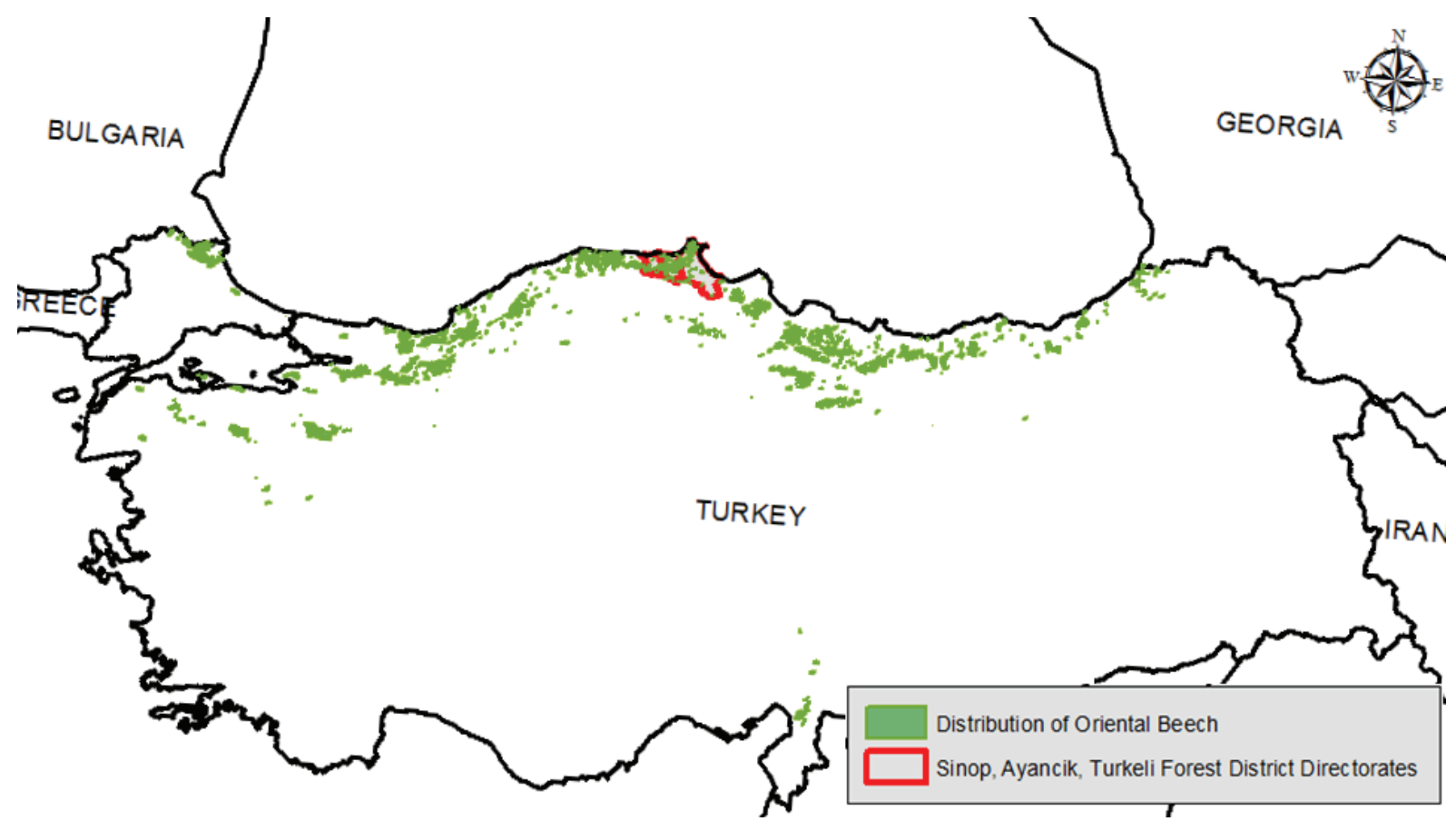

Figure 1. Map of Oriental beech distribution in Turkey (General Directorate of Forestry 2015) and the study locations of the Oriental beech stands.

Mapa de la distribución de los bosques de hayas orientales en Turquía (General Directorate of Forestry 2015) y los lugares de estudio de los rodales.

number of trees that are equally distributed diameter classes. In addition to that, the tallest trees by the 100 tallest trees per hectare in each sample area were measured. The hereby study calculates mean diameter, mean height, top height and tree number, basal area and volume values, as well as stand age, site index and density level by using data from sampling areas, in order to establish stand growth models in form of density-variable yield table.

For sample areas, mean diameter weighted by basal area of stands is used as a basis for calculation of mean diameter. Stand mean height was calculated via mean height weighted by basal area. The number of trees per hectare was calculated by multiplying the number of trees thicker than $8 \mathrm{~cm}$ in sampling areas with hectare conversion coefficient. Stand basal area was found through addition of basal areas of single trees at the site and their multiplication for conversion to hectare. Stand top height was calculated by means of arithmetic mean of highest trees in the sampling area pursuant to 100 -tree per hectare calculation. The volume estimates in the sampling area made use of a volume equation developed by (Carus 1998) on Oriental Beech, given in equation number (1) below. Upon conversion of total single tree volumes in hectare via doubleentry tree volume equations, we attained stand volumes. In the model, "d" signifies diameter at breast height while " $h$ " shows tree height.

$$
V=d^{2} \cdot(-0.000116988+0.0000397641 \cdot h)
$$

(Carus 1998)

Site index of stands was calculated by site index models obtained through Generalized Algebraic Difference Approach (GADA). Hossfeld growth function was used to model the changes in the height values of trees at different ages according to age and other variables (base age and site index). These functions were rearranged by Cieszewski (2001) using GADA and were transformed into a model structure which can be used to make dominant height estimations for site and base ages. The site index model explains $97.6 \%$ of the variance in height $\left(\mathrm{R}^{2}{ }_{\text {adj }}\right)$. In the equation, the root mean square error $(\mathrm{RMSE})=1.07$ $\mathrm{m}$, bias was $-0.49 \mathrm{~m}$, while mean absolute error (MAE) is $0.78 \mathrm{~m}$. The functional structure and parameter estimate value of the established site index model were given in equation number (2). In this model, $h$ signifies top height estimated for a certain $t$ age, $t_{0}$ was standard age, whereas $h_{0}$ shows top height at standard age of $t_{0}$, which in other words, is the site index. Stand site index can be calculated directly using a base age $\left(\mathrm{t}_{0}\right)$, stand age $(\mathrm{t})$ and dominant height (h) determined via equality numbered 2 (Ercanlı et al. 2014). 


$$
h_{0}(S . I)=h \cdot \frac{t_{0}^{1.2078} \cdot\left(t^{1.2078} \cdot\left[h-34.2709+\sqrt{\left.(h-34.2709)^{2}+2 \cdot h \cdot \frac{e^{-19,9636}}{t_{0}^{1,2078}}\right]+e^{-19.9636}}\right)\right.}{t^{1.2078} \cdot\left(t _ { 0 } ^ { 1 . 2 0 7 8 } \cdot \left[h-34.2709+\sqrt{\left.\left.(h-34.2709)^{2}+2 \cdot h \cdot \frac{e^{-19.9636}}{t_{0}^{1.2078}}\right]+e^{-19.9636}\right)}\right.\right.}
$$

Relative Density Index (RD), developed by (Curtis 1982), is used for calculating stand density (Vanclay 1994). In the equation (equation 3$), \mathrm{BA}\left(\mathrm{m}^{2} \mathrm{ha}^{-1}\right)$ shows total calculated basal area, and $(\mathrm{cm})$ is the quadratic mean diameter, weighted by the basal area.

Relative Density Index (RD):

$$
\mathrm{RD}=\mathrm{BA} / \sqrt{\overline{\mathrm{d}}_{\mathrm{q}}}
$$

Descriptive statistics including mean, minimum, maximum and standard deviation of the plot characteristics, such as stand age, site index, stand density, quadratic mean diameter, mean height weighted by basal area, stand basal area, stand volume and number of trees per hectare were listed below (table 1).

Volume yield is calculated by adding the current standing volume (remaining stand volume) and the sum of the volume removed (removed stand volume) in all previous periods (Pretzcsh 2009). Stand volume and yield elements such as number of trees per hectare, basal area, volume, quadratic mean diameter and mean height of main stand are calculated as a function of stand age, site index and stand density. Regression equations using the Forward Selection Method, Backward Selection Method and Stepwise Selection Method techniques implemented using SPSS version 19.0 (SPSS Institute Inc. 2010).

Removed stand volume and volume elements are necessary in order to determine total stand volume. The total stand volume is equal to the sum of the main stand volume at that age and the stand volume removed until the mentioned age (Kalıpsiz 1962). Volume and volume elements of the removed stand can be directly fixed through continuous sampling areas, nevertheless, in the absence of continuous sampling areas, they can be estimated via temporary sampling areas (Vanclay 1994). In this study, removed stand elements are calculated using dying and dead trees data in the sampling area. This removed volume (the sum of the thinned volume) may amount to $20-60 \%$ of the total volume production depending on the self-thinning and the intensity of thinning operations (Vanclay 1994, Pretzcsh 2009).

In addition to volume and volume elements of the main and removed stands on yield tables, in this study, we calculated other elements on yield table, including the current annual volume increment, the mean annual volume increment (periodic annual volume increment $=$ PAI) and total stand volume. Mean annual increment (MAI) and current annual increment (CAI) are important for estimating the stand growth phase in the period among inventories, planning future stand treatment, analyzing thinning responses and calculating the quantity of removals (Pretzcsh 2009).

Two statistical criteria obtained from the residuals were examined: the adjusted coefficient of determination $\left(\mathrm{R}^{2} \mathrm{adj}\right)$ and root mean square error (RMSE). The model evaluation criteria were as follows:

$$
R M S E=\sqrt{\frac{\sum_{i=1}^{n}\left(y_{i}-\hat{y}_{i}\right)^{2}}{n-p}}
$$

Table 1. The minimum, maximum, mean, and standard deviation of main characteristics of the study material.

Mínimo, máximo, media y desviación estándar de las principales características del material de estudio.

\begin{tabular}{lcccc}
\hline Variable & Mean & Minimum & Maximum & Std. deviation \\
\hline Age (year) & 64.6 & 24.0 & 131.0 & 18.1 \\
Site index (m) & 26.1 & 19.0 & 35.9 & 2.7 \\
Stand density & 6.3 & 2.2 & 10.8 & 2.0 \\
Mean diameter (cm) & 29.1 & 10.4 & 54.8 & 7.6 \\
Mean height (m) & 19.0 & 10.0 & 32.3 & 3.5 \\
Basal area $\left(\mathrm{m}^{2} \mathrm{ha}^{-1}\right)$ & 33.7 & 11.0 & 61.0 & 12.3 \\
Volume $\left(\mathrm{m}^{3} \mathrm{ha}^{-1}\right)$ & 307.7 & 65.1 & 994.6 & 178.3 \\
\hline Number of stems (number ha-1) & 586.9 & 137.5 & $3,100.0$ & 377.9 \\
\hline
\end{tabular}




$$
R_{a d j}^{2}=1-\frac{(n-1) \sum_{i=1}^{n}\left(y_{i}-\hat{y}_{i}\right)^{2}}{(n-p) \sum_{i=1}^{n}\left(y_{i}-\bar{y}_{i}\right)^{2}}
$$

Where: $\mathrm{n}$ is the number of observations; $p$ is the number of parameters; $y_{i}, \hat{y}_{i}$, and $\bar{y}_{i}$ are observed, predicted and mean values of the dependent variable, respectively.

\section{RESULTS}

The density-variable yield tables were created for 20130 years, I-II-III-IV-V site index, and 3-10 stand density. Not all table values were provided. In this study stand, age ranges from 24 to 131 years. Model results are valid for up to 130 years old. The other four stand variables in addition to the basal area value of old growth stands of 130 -yearold may not be accurately obtained with this model.

The data evaluated in this study were obtained from the study conducted by Altun et al. (2013). The quadratic mean diameter $\left(\bar{d}_{q}\right)$, mean height $\left(\bar{h}_{q}\right)$, tree density $(\mathrm{N})$, basal area (BA) and stand volume $(V)$ of the main stand were calculated in density-variable yield tables as functions of stand age (A), site index (SI) and stand density (RD) via regression equations (equations 6-10). Statistical information about the regression equations is provided in table 2. Subsequently, the change in the main and removed stand elements of the density-variable yield tables as well as the other elements of the yield table were calculated on the basis of stands.

Table 2. Certain statistical information about growth relations of main stands.

Información estadística acerca de las relaciones de crecimiento de los rodales principales.

\begin{tabular}{ccccrc}
\hline Variable & $\mathrm{R}_{\text {adj }}^{2}$ & RMSE & $\mathrm{f}$ & $\mathrm{F}_{\text {ratio }}$ & $P$ \\
\hline $\bar{d}_{q}$ & 0.732 & 3.322 & - & 276.93 & $<0.001$ \\
$\bar{h}_{q}$ & 0.957 & 0.034 & 1.00058 & 1224.75 & $<0.001$ \\
$\mathrm{~N}$ & 0.782 & 0.151 & 1.01832 & 140.53 & $<0.001$ \\
$\mathrm{BA}$ & 0.968 & 0.066 & 1.00217 & 2098.34 & $<0.001$ \\
$\mathrm{~V}$ & 0.938 & 0.136 & 1.00933 & 1192.90 & $<0.001$ \\
\hline
\end{tabular}

*f (correction factors of logarithmic functions)

$$
\begin{gathered}
\hat{d}_{q}=-4.206+\left[0.3172925 \cdot\left(\operatorname{Ln} \frac{A \cdot S I^{2}}{R D}\right) \cdot(\operatorname{LnRD})\right]+(0.00807576 . A \cdot S I) \\
\operatorname{Ln} \hat{h}_{q}=1.282-\left(\frac{24.2826}{A}\right)+(1.2918 . \operatorname{LnSI})-(0.04049 . R D)+(0.022025 . \operatorname{LnA} \cdot \operatorname{LnSI} \cdot \operatorname{LnRD}) \\
\operatorname{Ln} \widehat{N}=5.330+(0.02447 . S I)+(0.130059 . R D)-\left(\frac{1.777258}{R D}\right)-(0.000376 . A . S I)+\left(\frac{755.598841}{A . S I}\right) \\
\operatorname{Ln} \widehat{B A}=1.8039-\left(\frac{27.0463}{A}\right)-(0.010377 . S I)+(0.86706 . \operatorname{Ln} R D) \\
\operatorname{Ln} \widehat{V}=6.2724-\left(\frac{55.33973}{A}\right)-\left(\frac{47.0519}{S I}\right)+(1.0006207 . \operatorname{Ln} R D)
\end{gathered}
$$

All coefficients in regression equations are found significant at significance level of $P<0.001$. Among the developed regression models, stand basal area $\left(\mathrm{R}^{2}=0.97\right)$ provided the highest relation, followed by models organized for mean height $\left(R^{2}=0.96\right)$, stand volume $\left(R^{2}=0.94\right)$, number of stand trees $\left(R^{2}=0.78\right)$ and mean diameter $\left(\mathrm{R}^{2}=0.73\right)$, respectively. As the logarithmic values of dependent variables in equations 7, 8, 9 and 10 are estimated; it is necessary to extract the anti-logarithm of these values after correction via $f$ factor calculated under equation 11 (Baskerville 1972).

$$
f=e^{0.5 \times S_{y \cdot x}^{2}}
$$

The variance of mean diameter of main stands which are found using the aforesaid regression models, as well as of the number of trees per hectare and stand volume, depending on stand age, site index and stand density are 
given in figures 2-6. The comparison of yield tables were carried out using the volume and volume increment values at the stand density of $9(9 \mathrm{RD})$ which is considered as normal in this study. Also, in this study, rotation age is taken as 100 years. The rotation age (100 years) is commonly used in these stands which are managed for production purposes. The change of some stand elements according to stand ages, site index and stand density are given in table 3.

Mean diameter of pure Oriental beech stands increases as site quality is increased and stand grows older. The mean diameter falls as stand density rises (figure $2 \mathrm{~A}$ and figure 2B). A hundred year-old stands of normal density (9 RD) have a mean diameter of 35.3, 32.6, 29.8, 27.0 and $24.2 \mathrm{~cm}$, respectively, from high to low site index (I-II-
III-IV-V site classes). The mean diameters of 100-yearold stands of the middle site index group (III site class) are $31.4,30.7,30.2$ and $29.8 \mathrm{~cm}$ from low to high density (3-5-7-9 RD) levels, respectively (table 3).

As for even-aged Oriental beech stands, the main stand volume values increase depending on age, site index and density (figures $3 \mathrm{~A}$ and $3 \mathrm{~B}$ ). Main stand volumes of 70 year-old stands at 9 stand density and site classes I, III and V are 502.4, 357.8 and $207.9 \mathrm{~m}^{3}$ respectively; for stands of 100 years volumes are 636.8, 453.6 and 263.6 $\mathrm{m}^{3}$, and for 130 year-olds volumes are 723.6, 515.4 and $299.5 \mathrm{~m}^{3}$, respectively. On the other hand, the main stand volumes of 70 year-olds at III, SI and density of 3-5-7-9 $\mathrm{RD}$ are $119.2,198.7,278.3$ and $357.8 \mathrm{~m}^{3}$, while the volume for 100 year-olds are 151.1, 251.9, 352.7 and $453.6 \mathrm{~m}^{3}$,
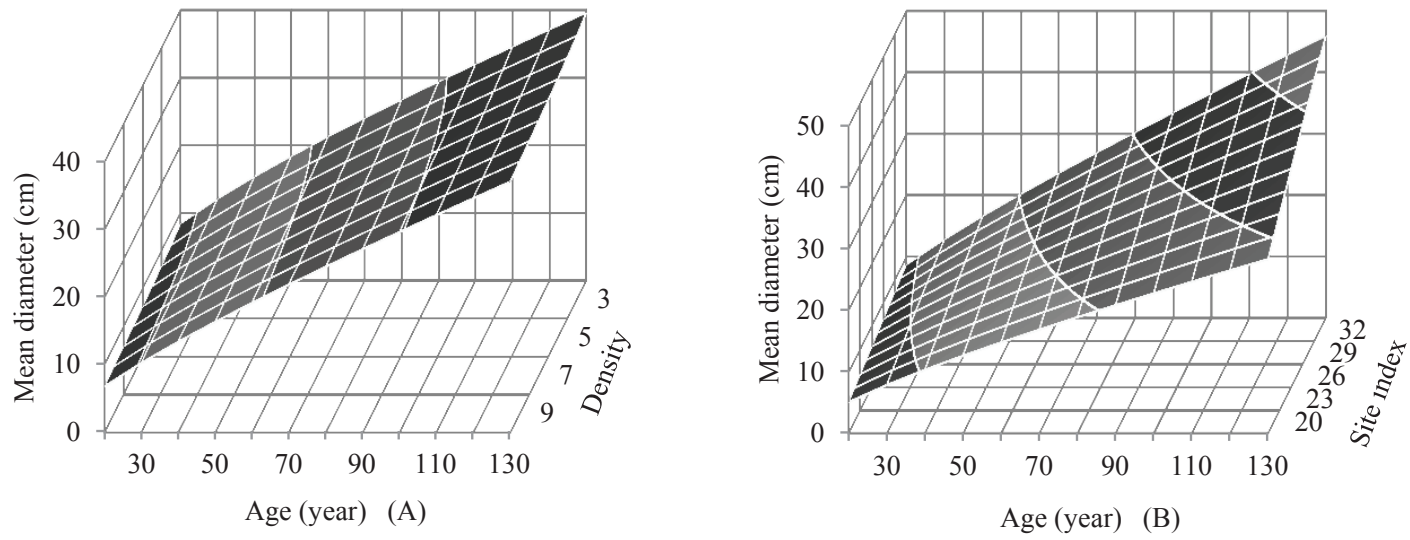

Figure 2. Change in mean diameter according to (A) stand age and stand density for middle site index class, and (B) stand age and site index for normal stand density.

Cambio en el diámetro promedio de acuerdo a (A) la edad del rodal y la densidad del rodal para la clase de índice de sitio medio y (B) la edad del rodal y el índice de sitio para densidad de rodal normal.
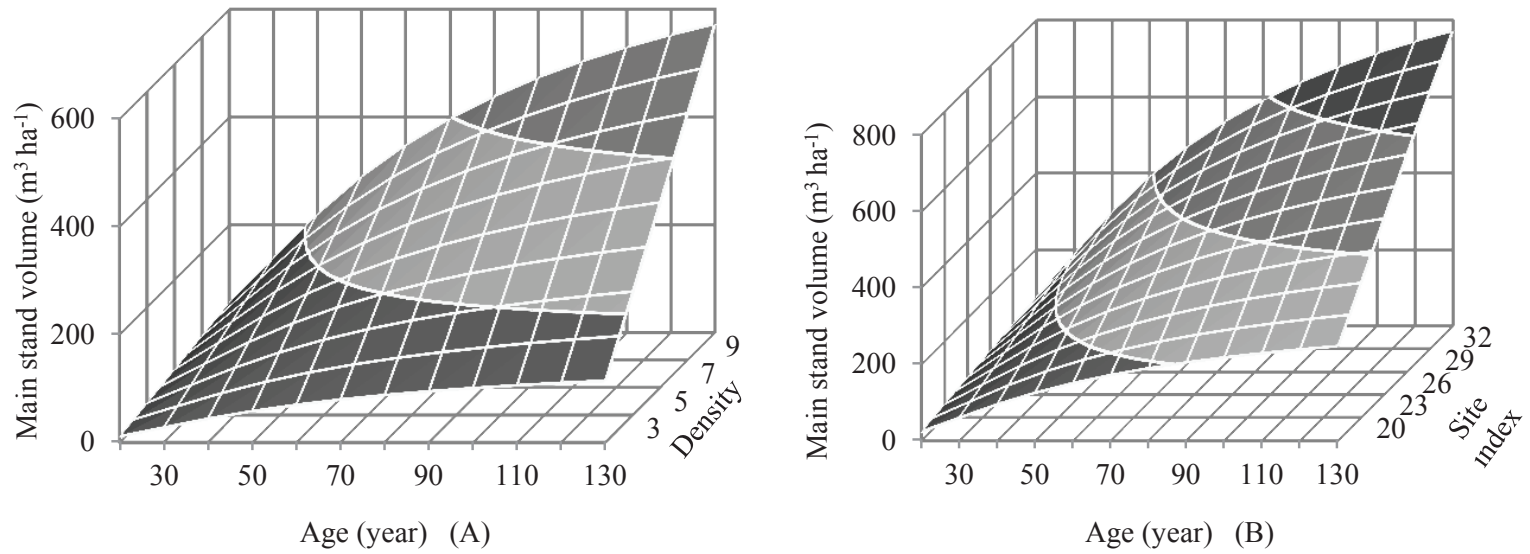

Figure 3. Change of main stand volume according to (A) stand age and stand density for middle site index class, and (B) stand age and site index for normal stand density.

Cambio del volumen principal del rodal de acuerdo a (A) la edad del rodal y la densidad del rodal para la clase de índice de sitio medio y (B) la edad del rodal y el índice de sitio para densidad de rodal normal. 

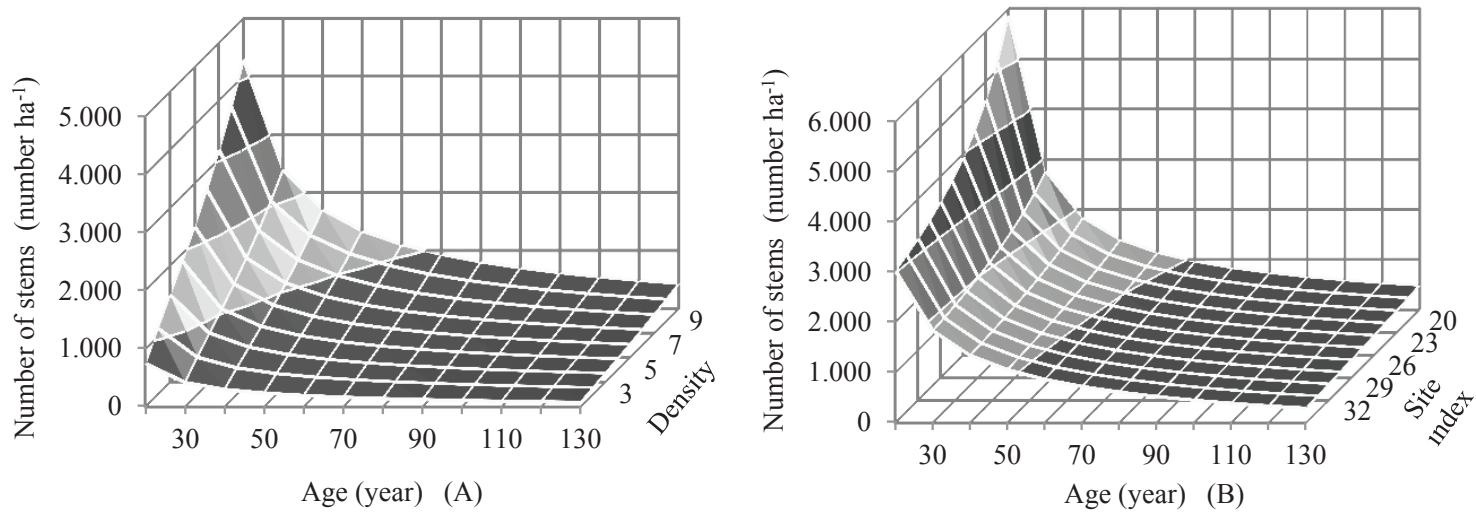

Figure 4. Change of number of stems according to (A) stand age and stand density for middle site index class, and (B) stand age and site index for normal stand density.

Cambio de la cantidad de tallos de acuerdo a (A) la edad del rodal y la densidad del rodal para la clase de índice de sitio medio y (B) la edad del rodal y el índice de sitio para densidad de rodal normal.
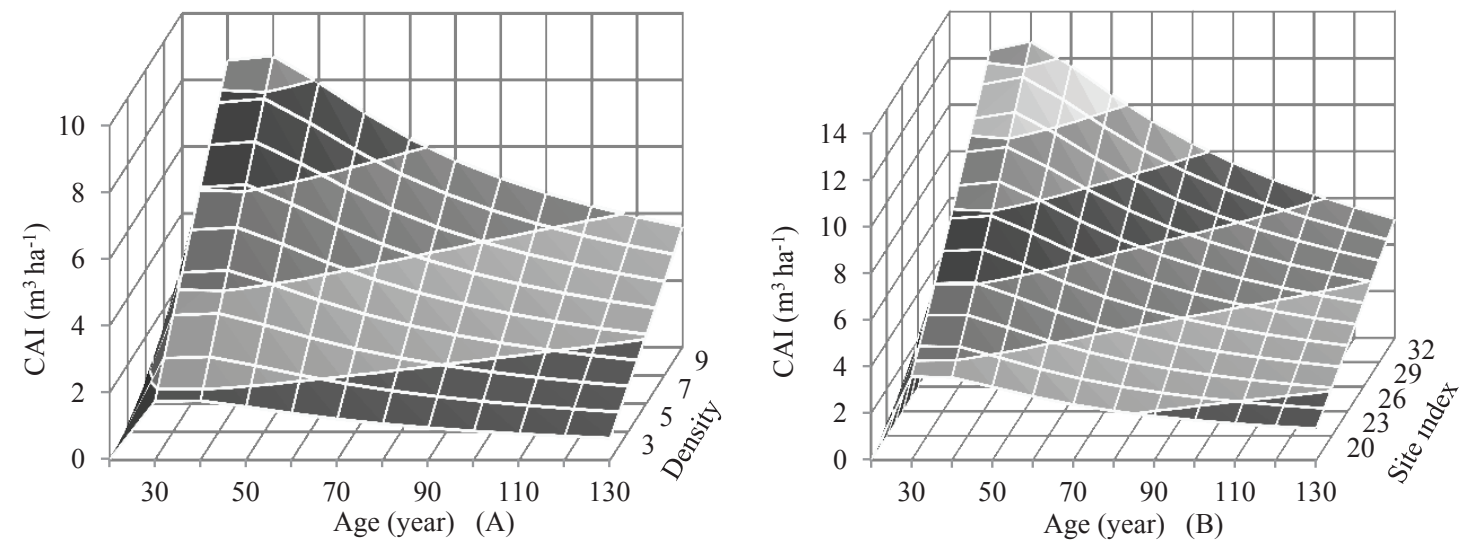

Figure 5. Change of current annual increment according to (A) stand age and stand density for middle site index class, and (B) stand age and site index for normal stand density.

Cambio de incremento anual actual de acuerdo a (A) la edad del rodal y la densidad del rodal para la clase de índice de sitio medio y (B) la edad del rodal y el índice de sitio para densidad de rodal normal.
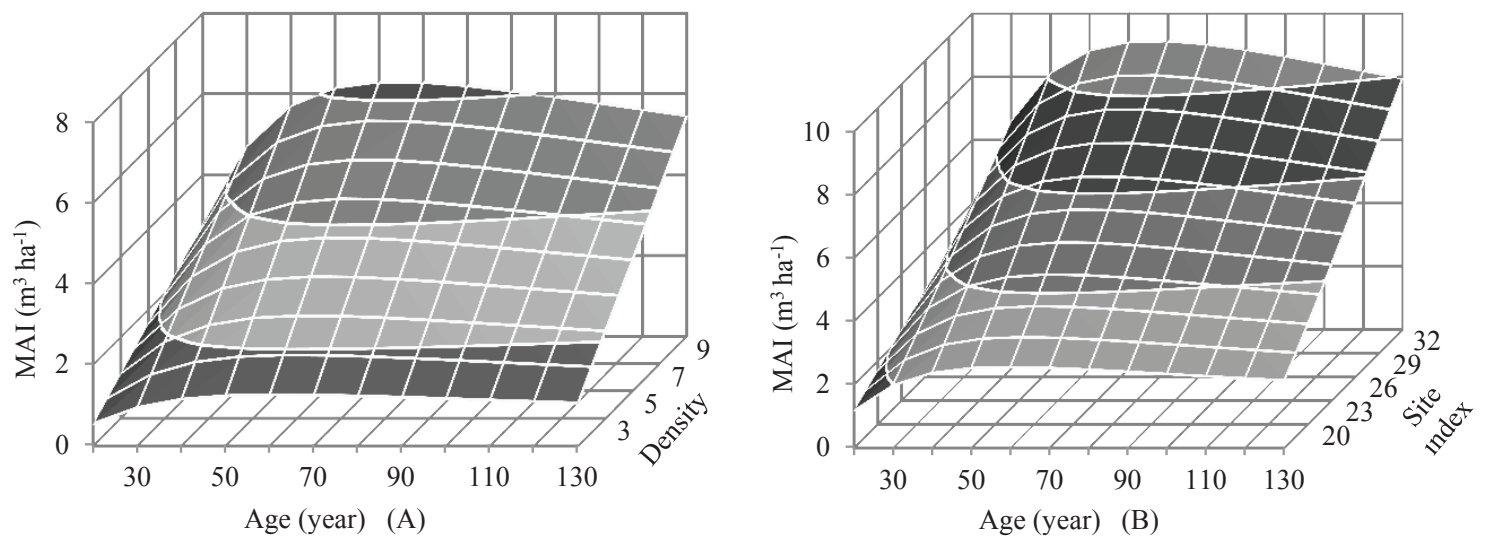

Figure 6. Change of mean annual increment according to (A) stand age and stand density for middle site index class, and (B) stand age and site index for normal stand density.

Cambio de incremento anual medio de acuerdo a (A) la edad del rodal y la densidad del rodal para la clase de índice de sitio medio y (B) la edad del rodal y el índice de sitio para densidad de rodal normal. 
Table 3. Change of some stand elements according to stand ages, site index and stand density.

Cambio de algunos elementos del rodal de acuerdo a la edad del rodal, el índice de sitio y la densidad.

\begin{tabular}{|c|c|c|c|c|c|c|c|c|c|c|c|}
\hline SI & $\mathrm{RD}$ & A & $\bar{d}_{q}$ & $\bar{h}_{q}$ & BA & $\mathrm{V}_{\mathrm{ms}}$ & $\mathrm{N}$ & $\sum \mathrm{V}_{\mathrm{rs}}$ & CAI & $\mathrm{V}_{\mathrm{ts}}$ & MAI \\
\hline $\mathrm{m}$ & & year & $\mathrm{cm}$ & $\mathrm{m}$ & $\mathrm{m}^{2} \mathrm{ha}^{-1}$ & $\mathrm{~m}^{3} \mathrm{ha}^{-1}$ & $\mathrm{Nha}^{-1}$ & $\mathrm{~m}^{3} \mathrm{ha}^{-1}$ & $\mathrm{~m}^{3} \mathrm{ha}^{-1}$ & $\mathrm{~m}^{3} \mathrm{ha}^{-1}$ & $\mathrm{~m}^{3} \mathrm{ha}^{-1}$ \\
\hline \multirow{16}{*}{32} & \multirow{4}{*}{9} & 40 & 16.0 & 17.2 & 29.0 & 277.7 & 1,357 & 23.1 & 11.72 & 300.8 & 7.52 \\
\hline & & 70 & 26.0 & 24.4 & 38.7 & 502.4 & 734 & 87.4 & 8.56 & 589.7 & 8.42 \\
\hline & & 100 & 35.3 & 28.8 & 43.5 & 636.8 & 463 & 161.3 & 6.26 & 798.1 & 7.98 \\
\hline & & 130 & 44.2 & 31.8 & 46.3 & 723.6 & 305 & 230.7 & 4.74 & 954.3 & 7.34 \\
\hline & \multirow{4}{*}{7} & 40 & 16.3 & 17.3 & 23.3 & 215.9 & 989 & 18.6 & 9.13 & 234.5 & 5.86 \\
\hline & & 70 & 26.3 & 24.4 & 31.2 & 390.7 & 535 & 67.2 & 6.59 & 457.9 & 6.54 \\
\hline & & 100 & 35.7 & 28.6 & 35.0 & 495.2 & 337 & 121.9 & 4.77 & 617.2 & 6.17 \\
\hline & & 130 & 44.6 & 31.4 & 37.2 & 562.7 & 222 & 172.8 & 3.58 & 735.5 & 5.66 \\
\hline & \multirow{4}{*}{5} & 40 & 16.7 & 17.1 & 17.4 & 154.2 & 689 & 14.1 & 6.55 & 168.3 & 4.21 \\
\hline & & 70 & 26.8 & 23.8 & 23.3 & 279.0 & 373 & 48.8 & 4.69 & 327.8 & 4.68 \\
\hline & & 100 & 36.1 & 27.5 & 26.1 & 353.7 & 235 & 86.9 & 3.37 & 440.6 & 4.41 \\
\hline & & 130 & 45.1 & 30.1 & 27.8 & 401.8 & 155 & 122.0 & 2.51 & 523.8 & 4.03 \\
\hline & \multirow{4}{*}{3} & 40 & 17.3 & 16.1 & 11.2 & 92.5 & 419 & 9.1 & 3.96 & 101.6 & 2.54 \\
\hline & & 70 & 27.5 & 21.8 & 14.9 & 167.3 & 227 & 30.0 & 2.81 & 197.3 & 2.82 \\
\hline & & 100 & 36.9 & 25.0 & 16.8 & 212.1 & 143 & 52.3 & 2.00 & 264.4 & 2.64 \\
\hline & & 130 & 45.9 & 27.0 & 17.9 & 241.0 & 94 & 72.5 & 1.48 & 313.6 & 2.41 \\
\hline \multirow{16}{*}{26} & \multirow{4}{*}{9} & 40 & 13.6 & 12.6 & 27.2 & 197.8 & 1,470 & 8.0 & 7.87 & 205.8 & 5.14 \\
\hline & & 70 & 22.0 & 17.9 & 36.4 & 357.8 & 803 & 38.6 & 5.61 & 396.4 & 5.66 \\
\hline & & 100 & 29.8 & 21.0 & 40.9 & 453.6 & 529 & 79.4 & 4.12 & 533.0 & 5.33 \\
\hline & & 130 & 37.3 & 23.2 & 43.5 & 515.4 & 369 & 122.0 & 3.20 & 637.4 & 4.90 \\
\hline & \multirow{4}{*}{7} & 40 & 13.9 & 12.8 & 21.9 & 153.8 & 1,071 & 6.7 & 6.14 & 160.5 & 4.01 \\
\hline & & 70 & 22.4 & 18.0 & 29.3 & 278.3 & 585 & 30.4 & 4.34 & 308.6 & 4.41 \\
\hline & & 100 & 30.2 & 21.0 & 32.9 & 352.7 & 385 & 60.9 & 3.15 & 413.7 & 4.14 \\
\hline & & 130 & 37.7 & 23.0 & 35.0 & 400.8 & 269 & 92.4 & 2.43 & 493.2 & 3.79 \\
\hline & \multirow{4}{*}{5} & 40 & 14.3 & 12.7 & 16.4 & 109.8 & 746 & 5.3 & 4.41 & 115.1 & 2.88 \\
\hline & & 70 & 22.8 & 17.6 & 21.9 & 198.7 & 407 & 22.5 & 3.10 & 221.2 & 3.16 \\
\hline & & 100 & 30.7 & 20.4 & 24.6 & 251.9 & 268 & 43.9 & 2.23 & 295.8 & 2.96 \\
\hline & & 130 & 38.2 & 22.2 & 26.1 & 286.2 & 187 & 65.6 & 1.71 & 351.8 & 2.71 \\
\hline & \multirow{4}{*}{3} & 40 & 14.9 & 12.1 & 10.5 & 65.9 & 454 & 3.5 & 2.66 & 69.3 & 1.73 \\
\hline & & 70 & 23.5 & 16.3 & 14.0 & 119.2 & 248 & 13.9 & 1.86 & 133.0 & 1.90 \\
\hline & & 100 & 31.4 & 18.6 & 15.8 & 151.1 & 163 & 26.3 & 1.32 & 177.4 & 1.77 \\
\hline & & 130 & 39.0 & 20.1 & 16.8 & 171.7 & 114 & 38.8 & 1.00 & 210.4 & 1.62 \\
\hline
\end{tabular}


Table 3 Continued

\begin{tabular}{rrrrrrrrrrr}
\hline & 40 & 11.0 & 8.6 & 25.6 & 114.9 & 1,727 & 1.0 & 4.34 & 116.0 & 2.90 \\
9 & 70 & 17.9 & 12.1 & 34.2 & 207.9 & 920 & 10.3 & 2.97 & 218.2 & 3.12 \\
& 100 & 24.2 & 14.1 & 38.4 & 263.6 & 624 & 26.0 & 2.15 & 289.6 & 2.90 \\
& 130 & 30.2 & 15.5 & 40.9 & 299.5 & 456 & 45.0 & 1.69 & 344.4 & 2.65 \\
\hline & 40 & 11.3 & 8.8 & 20.6 & 89.4 & 1,259 & 1.0 & 3.39 & 90.3 & 2.26 \\
& 70 & 18.3 & 12.2 & 27.5 & 161.7 & 670 & 8.4 & 2.31 & 170.1 & 2.43 \\
& 100 & 24.6 & 14.2 & 30.9 & 205.0 & 455 & 20.5 & 1.66 & 225.5 & 2.26 \\
& 130 & 30.6 & 15.5 & 32.9 & 232.9 & 333 & 34.8 & 1.30 & 267.6 & 2.06 \\
\hline & 40 & 11.7 & 8.8 & 15.4 & 63.8 & 877 & 0.8 & 2.43 & 64.6 & 1.62 \\
& 70 & 18.7 & 12.1 & 20.5 & 115.5 & 467 & 6.4 & 1.66 & 121.9 & 1.74 \\
& 100 & 25.1 & 13.9 & 23.1 & 146.4 & 317 & 15.0 & 1.18 & 161.4 & 1.61 \\
& 130 & 31.1 & 15.1 & 24.6 & 166.3 & 232 & 24.9 & 0.92 & 191.2 & 1.47 \\
\hline & 40 & 12.3 & 8.4 & 9.9 & 38.3 & 533 & 0.5 & 1.46 & 38.8 & 0.97 \\
& 70 & 19.4 & 11.3 & 13.2 & 69.3 & 284 & 3.9 & 0.99 & 73.1 & 1.04 \\
& 100 & 25.8 & 12.9 & 14.8 & 87.8 & 193 & 8.8 & 0.70 & 96.6 & 0.97 \\
& 130 & 31.9 & 13.9 & 15.8 & 99.8 & 141 & 14.4 & 0.54 & 114.1 & 0.88 \\
\hline
\end{tabular}

SI site index, RD relative density, A age, quadratic median diameter, mean height weighted by basal area, $\mathrm{BA}$ basal area, $\mathrm{V}_{\mathrm{ms}}, \mathrm{V}_{\mathrm{rs}}$ and $\mathrm{V}_{\mathrm{ts}}$ main, removed and total stand volume, respectively, $\mathrm{N}$ number of stems per hectare, CAI current annual increment and MAI mean annual increment.

and the volumes of 130 year-old stands are 171.1, 286.2, 400.8 and $515.4 \mathrm{~m}^{3}$, respectively (table 3 ).

According to the data model results main stand volume of 130 year-old at 9 stand density and $32 \mathrm{~m}$ site index is $723.6 \mathrm{~m}^{3} \mathrm{ha}^{-1}$ (table 3 ). This value is smaller than actual stand volumes of only 7 sample areas. Also, the maximum actual stand volume value is $994.6 \mathrm{~m}^{3} \mathrm{ha}^{-1}$ (table 1). Site index and stand density values of this sample area are 33.5 $\mathrm{m}$ and 10.26 , respectively. It has a high volume value compared with the other stand volumes of sample areas. On the other hand, main stand volume of 130 year-old stands at 10.5 stand density and $32.0 \mathrm{~m}$ site index is $844 \mathrm{~m}^{3} \mathrm{ha}^{-1}$ for equation 10. As a result, we can say that the volume model is an accurate estimate for Oriental beech stands.

For Oriental beech stands, the number of stems per hectare decreases as the stand grows older, and site index rises; the number, however, increases in parallel with stand density (figures $4 \mathrm{~A}$ and $4 \mathrm{~B}$ ). Normal stand density and number of stems per hectare at site index groups of $\mathrm{I}$, III and V are 3,116, 3,696 and 5,164 at 20 years; 734, 803 and 920 at 70 years; and 305, 369 and 456 at 130 years. Stems per hectare in middle site index class and at density levels of 3, 5, 7 and 9 are 1,141, 1,876, 2,694 and 3,696 at 20 years; 248, 407, 585 and 803 at 70 years; and 114, 187, 269 and 369 , at 130 years (table 3 ).
The current annual volume increment of Oriental beech stands reaches a peak at 30-35 years at all site index groups and density levels, and begins to fall afterwards (figures $5 \mathrm{~A}$ and $5 \mathrm{~B})$. As the site index gets better and stand density gets higher, current annual volume increment increases as well. For 35 year-old stands of normal density (9 RD), current annual increment changes as 11.72, 9.36, 7.87, 6.05 and $4.34 \mathrm{~m}^{3} \mathrm{ha}^{-1}$ from higher to lower site index (I-II-III-IV-V site classes); while 35 year-old stands in middle site class (III site class) yielded values of 2.66, $4.48,6.84$ and $7.87 \mathrm{~m}^{3} \mathrm{ha}^{-1}$ from low to higher density (35-7-9 RD), respectively (table 3).

Mean annual volume increment peaks up at $65-75$ years at all site classes and density levels, before beginning to decline (figures 6A and 6B). Mean annual volume increments for site classes I-II-III peak up at 65,70 and 75 years, respectively. Mean annual volume increment increases as site index gets better and stand density gets higher. For 70 year-old stands of normal density (9 RD), the mean annual increment is $8.42,7.03,5.66,4.35$ and $3.12 \mathrm{~m}^{3} \mathrm{ha}^{-1}$ from higher to lower site index (I-II-III-IV-V site classes), while for 70 year-old stands in middle site index class (III site class), these figures change as 1.90, $3.16,4.41$ and $5.66 \mathrm{~m}^{3} \mathrm{ha}^{-1}$ from low to high density (3-57-9 RD) (table 3). 


\section{DISCUSSION}

The acquired results will enable the accurate determination of volume and volume elements of the oriental beech stands in addition to enabling the management of the forests at full capacity. Thus, maximum benefit will have been attained from forest soil. In addition, the optimal and actual tree stock that stands should have will be compared.

Density-variable yield tables, which are established under this study (Sinop-Turkey), were compared with normal yield tables for pure Oriental beech established by (Carus 1998) for Turkey, and with yield tables for Euro- pean Beech in other countries (Ukraine, Dmitriev 1967; Sweden, Carbonnier 1971; Austria, Marschall 1975; Hungary, Mendlik 1983; Germany, Dittmar et al. 1986; Russia, Federal Agency of Forest Management of Russia 2008) (figures 7-9). For a more accurate result, the values in yield tables of stands of normal density in first site index category are compared. The normal density value of pure Oriental beech is taken as $9(9 \mathrm{RD})$, taking into account the density in the studied sampling areas.

At the end of our calculations, the quadratic mean diameters of Oriental beech stands of site index class I and normal density ( 9 stand density) found in our results are higher than those found in previous studies in stands aged
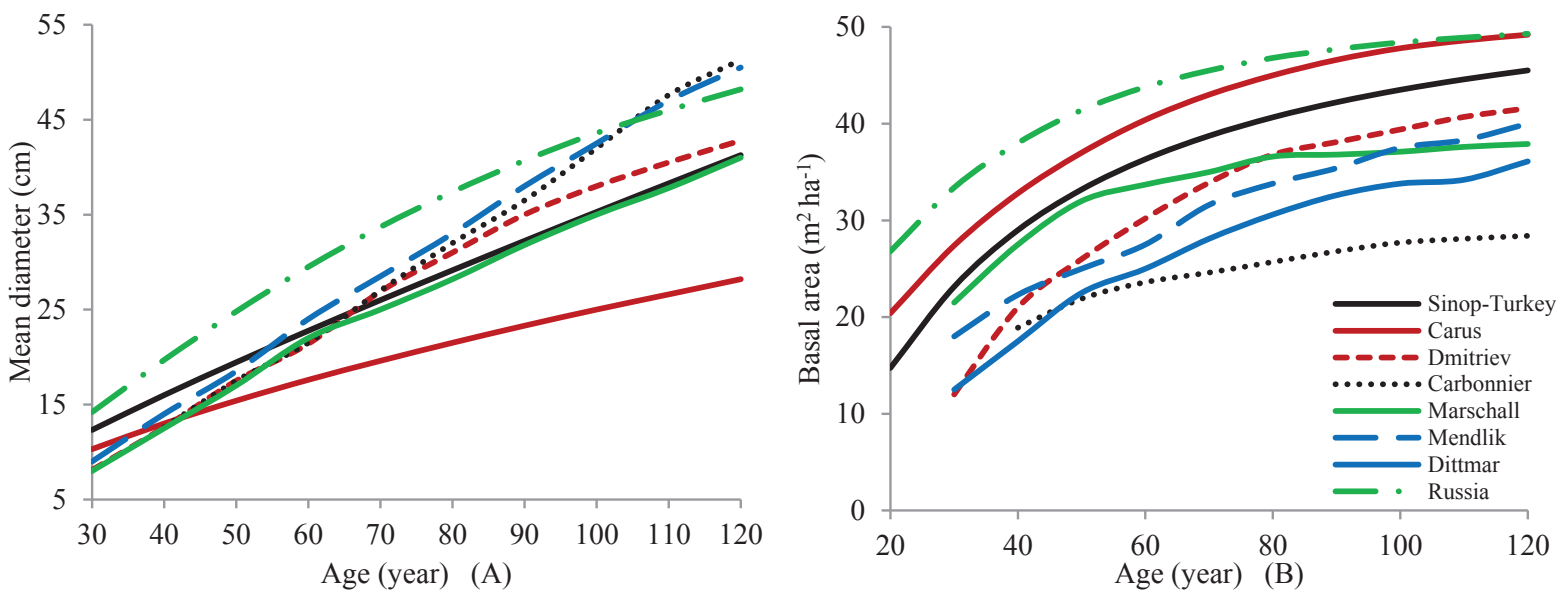

Figure 7. Comparison of Oriental beech stands for mean diameter (A) and basal area (B) based on data from the yield tables at normal stand density value and good site index.

Comparación de rodales de hayas orientales para un diámetro medio (A) y el área basal (B) basada en los datos de las tablas de rendimiento en un valor de densidad de rodal normal y un buen índice de sitio.
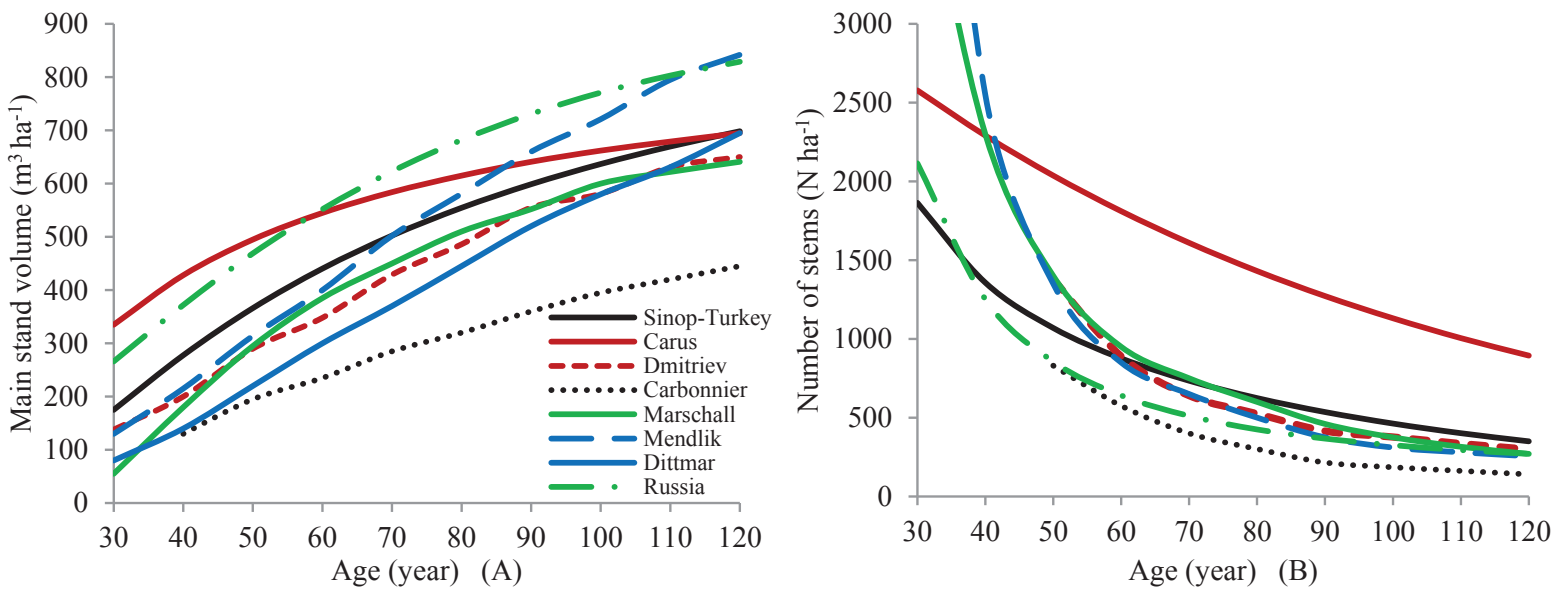

Figure 8. Comparison of Oriental beech stands for main stand volume (A) and number of stems (B) based on data from the yield tables at normal stand density and good site index.

Comparación de rodales de hayas orientales para un volumen de rodal principal (A) y la cantidad de tallos (B) basada en los datos de las tablas de rendimiento en un valor de densidad de rodal normal y un buen índice de sitio. 

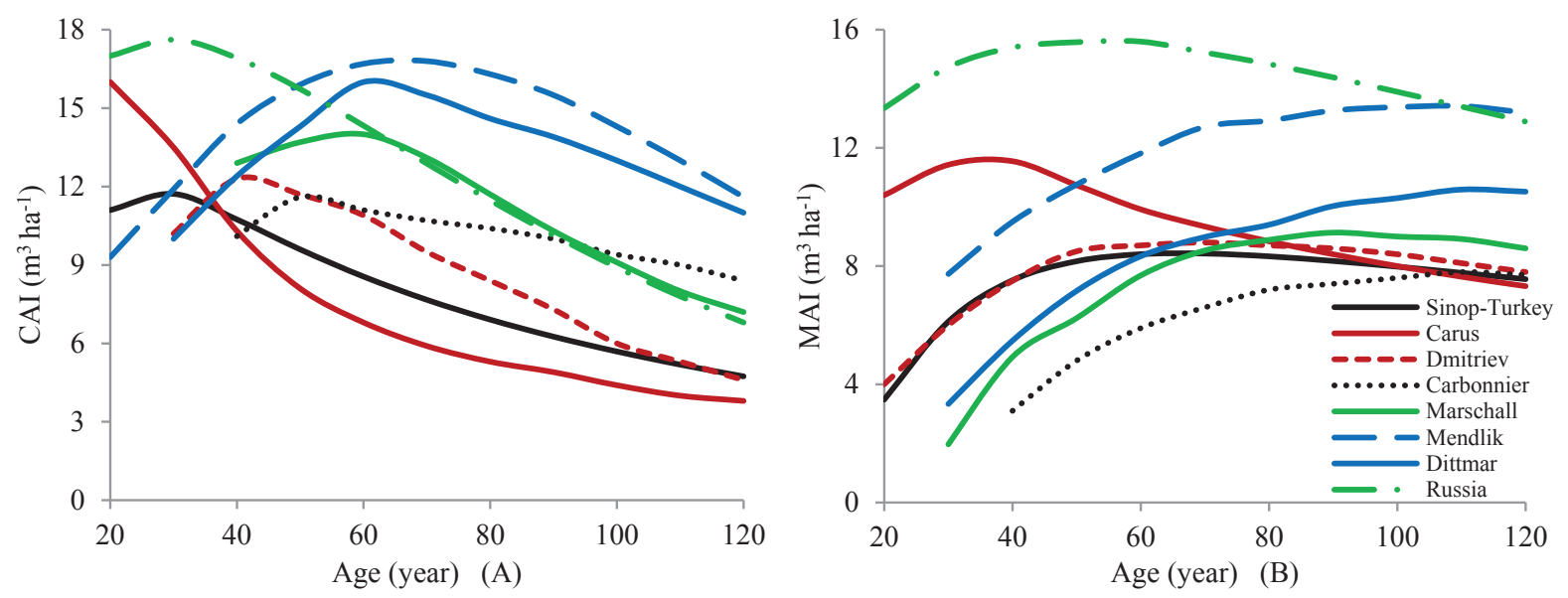

Figure 9. Comparison of Oriental beech stands for current (A) and mean annual increment (B) based on data from the yield tables at normal stand density value and good site index.

Comparación de rodales de hayas orientales para el incremento anual corriente (A) y medio (B) basada en los datos de las tablas de rendimiento en un valor de densidad de rodal normal y un buen índice de sitio.

between 35 and 55 (Dmitriev 1967, Carbonnier 1971, Marschall 1975, Mendlik 1983, Carus 1998), aged between 55-65 (Dmitriev 1967, Carbonnier 1971, Marschall 1975, Carus 1998) and in stands aged between 65 and 120 (Marschall 1975, Carus 1998) (figure 7A). The basal area values in this study are lower than those from (Carus 1998, Federal Agency of Forest Management of Russia 2008) at every age, but higher than results obtained from all other studies (figure 7B). Although basal area values increased with increasing age, the periodic rate of basal area increment slows with older stand age. However, basal area growth continues.

Main stand volumes of Oriental beech in site index class I and of normal density ( 9 stand density index) found in this study are lower than those found in previous studies for stands aged between 30 and 70 (Carus 1998, Federal Agency of Forest Management of Russia 2008) and for stands aged between 70 and 120 (Mendlik 1983, Carus 1998, Federal Agency of Forest Management of Russia 2008) (figure 8A). The stand volume values at which the mean annual volume increment values have reached maximum were determined in ascending order as Carbonnier (420.0 $\mathrm{m}^{3}$ at 110 years), Carus (428.0 $\mathrm{m}^{3}$ at 40 years), Dmitriev $\left(429.0 \mathrm{~m}^{3}\right.$ at 70 years), Sinop-Turkey $\left(502.4 \mathrm{~m}^{3}\right.$ at 70 years), Marschall (552.0 $\mathrm{m}^{3}$ at 90 years), Russia (552 $\mathrm{m}^{3}$ at 60 years $)$, Dittmar $\left(631.0 \mathrm{~m}^{3}\right.$ at 110 years $)$ and Mendlik $\left(721.0 \mathrm{~m}^{3}\right.$ at 100 years) (Figure $\left.8 \mathrm{~A}\right)$. The number of trees, calculated using stand models in this study, is higher than that found in previous studies done on stands aged between 35-60 (Federal Agency of Forest Management of Russia 2008), aged between 60 and 75 (Dmitriev 1967, Carbonnier 1971, Mendlik 1983, Federal Agency of Forest Management of Russia 2008) and aged between 75 and 120 (Dmitriev 1967, Carbonnier 1971, Marschall 1975,
Mendlik 1983, Federal Agency of Forest Management of Russia 2008) (figure 8B).

The maximum point on the curve of CAI (the inflection point) is the point corresponding to the fastest change in yield. The peak ages of current annual volume increment values from low to high are as follows: Carus (before 20 years), Sinop-Turkey (30-11.7 $\left.\mathrm{m}^{3}\right)$, Russia (30-17.6 m³), Dmitriev (40-12.3 $\left.\mathrm{m}^{3}\right)$, Carbonnier (50-11.6 m $\mathrm{m}^{3}$ ), Marschall (60-14.0 $\left.\mathrm{m}^{3}\right)$, Dittmar (60-16.0 $\left.\mathrm{m}^{3}\right)$ and Mendlik (70$16.8 \mathrm{~m}^{3}$ ), respectively (figure $9 \mathrm{~A}$ ).

Increasing yield of stand is an important topic in forestry studies. For this, firstly, it is important to know where the intersection point for current and mean annual volume increment is situated on the curves. This intersection point corresponds to the age when the mean annual volume increment is at a maximum. This point of intersection denotes the age of most efficient volume production over time and also, the point in which they intersect is called the biological rotation age. Thus, it is necessary to know the ages at which the mean annual increments of stands are at a maximum. As it can be seen in Figure 9B, the mean annual volume increment values of the beech stands in Turkey reach the maximum value after the beech stands in Russia and before the beech stands in Austria, Hungary, Germany and Sweden. The peak age and values of general mean volume increment are, from low to high: Carus (40-11.6 $\left.\mathrm{m}^{3}\right)$, Russia (60-15.6 $\left.\mathrm{m}^{3}\right)$, Dmitriev (70-8.8 $\left.\mathrm{m}^{3}\right)$, Sinop-Turkey (70-8.4 $\mathrm{m}^{3}$ ), Marschall (90-9.1 $\left.\mathrm{m}^{3}\right)$, Mendlik (100-13.4 $\left.\mathrm{m}^{3}\right)$ Carbonnier (110-7.8 $\left.\mathrm{m}^{3}\right)$ and Dittmar (110$10.6 \mathrm{~m}^{3}$ ) (figure 9B).

If our objective is to attain maximum wood yield from the forest, the values at ages when the mean annual volume increment of stands is at a maximum should be considered as highly important. The average diameter values at ages 
when the mean annual volume increment values have reached their peak values are determined as Carus $(13 \mathrm{~cm}$ at 40 years), Sinop-Turkey (26.0 $\mathrm{cm}$ at 70 years), Dmitriev $(26.9 \mathrm{~cm}$ at 70 years), Russia ( $29.5 \mathrm{~cm}$ at 60 years), Marschall (32.5 cm at 90 years), Mendlik (42.5 cm at 100 years) and Carbonnier ( $47.6 \mathrm{~cm}$ at 110 years) with diameters ranging from thin to thick respectively (figure 7B). On the other hand, when 100 years is taken as basis, it is observed that the mean diameter values at this age vary from thin to thick diameter as $25.0 \mathrm{~cm}$ (Carus), $35.0 \mathrm{~cm}$ (Marschall), $35.3 \mathrm{~cm}$ (Sinop-Turkey), $38.0 \mathrm{~cm}$ (Dmitriev), 42.0 $\mathrm{cm}$ (Carbonnier), $42.5 \mathrm{~cm}$ (Mendlik) and $43.6 \mathrm{~cm}$ (Russia) (figure 7B). If our objective is to acquire quality logs with a certain diameter, the year when the trees in the stands reach these diameter values has a critical importance. For example, if we take $36 \mathrm{~cm}$ diameter value as the basis, the age when the trees reach this value can be listed in ascending order as 75 years (Russia), 86 years (Mendlik), 88 years (Carbonnier), 93 years (Dmitriev), 102 years (SinopTurkey) and 103 years (Marschall) (figure 7B).

\section{CONCLUSIONS}

Based on density-variable yield tables derived in this study, it is now possible to make estimates according to a given age, site index class and stand density. The basal area, volume, mean diameter, and mean height of a main stand increases at the same age and density in parallel with site index; while number of trees fall under the same conditions. Number of trees, basal area and volume of main stands rise depending on stand density at the same age and site index class; whereas mean diameter and mean height decline. Current annual increment peaks at a certain age in every site index class and density levels before declining; besides, the increment rises as the site index grows better and stand density goes up. Total stand volume also increases with a better site index and higher stand density. The mean increment of general and main stand reaches the maximum level at the ages of 65 to 75 for every site index class and density, before falling. As site index prospers and stand density rises, the mean increment of the general and main stand goes up as well.

In this study, the growth models of pure and even-aged Oriental beech stands are established based on data from sampling areas. This research enables estimation of stand growth elements for various ages, site indexes and density levels of Oriental beech stands in Sinop Province. In particular, the increment and growth amount of thinned interfered Oriental beech stands can be calculated based on the equation systems established in this study.

Sinop Province, the northernmost point in Turkey, hosts the most important forests in the Black Sea region. Oriental beech stands in this province are of huge economic and biological importance. It is possible to protect and sustain the existence of Oriental beech stands only through forest management plans taking into account growth re- lations and stand structures in these forests. To that end, the recognition of growth relations regarding pure Oriental beech stands is crucial for preparation of forest management plans. The present study has determined the production potentials of pure and even-aged Oriental beech stands, and as such, has developed the required growth models for both management plans and silvicultural practices. The growth legality will bring about optimum utilization of ecological, economic and social functions of Oriental beech stands.

\section{ACKNOWLEDGEMENT}

The data for this study were obtained from Altun et al. (2012) project. The authors thank all who provided data. This work was supported by the TÜBİTAK - TOVAG (The Scientific and Technological Research Council of Turkey - Research Committee of Agriculture, Forestry and Veterinary), Project Number: 1070752.

\section{REFERENCES}

Alemdağ Ş. 1963. Some growth and yield in Oriental Beech ( $F a-$ gus orientalis Lipsky.) Forests in Tokat and rotation age to be applied to the forest. Ankara, Turkey. Forestry Research Institute of Ankara. Technical Bulletins Number 12.

Altun L, N Ay, B Serdar, N Köse. 2012. Determine the ecological based rotation length, anatomical, dendroclimatical, physical and mechanical characteristics of pure Oriental Beech (Fagus Orientalis Lipsky.) stands in Sinop Regional Directorate of Forestry. Trabzon, Turkey. Tübitak-Tovag Project. Project Number: 1070752.

Álvarez-González JG, A Zingg, KV Gadow. 2010. Estimating growth in beech forests: a study based on long term experiments in Switzerland. Annals Forest Science 67(3): 307-307.

Asan Ü. 1987. Site quality research of Oriental Beech (Fagus Orientalis Lipsky.) stands in West and Central Black Sea Region. İstanbul University Journal of Forestry Faculty A37(1): 106-130.

Atici E. 1998. Increment and growth in uneven-aged beech (Fagus orientalis Lipsly.) forests. PhD Thesis. Graduate School of Natural and Applied Sciences. İstanbul University, İstanbul, Turkey.

Baskerville G. 1972. Use of logarithmic regression in the estimation of plant biomass. Canadian Journal of Forest Research (2): 49-53.

Carbonnier C. 1971. Yield of beech in southern Sweden. Stockholm, Sweden. Royal College of Forestry. Studia Forestalia Number $91.68 \mathrm{p}$.

Carus S. 1998. Increment and growth in even aged beech (Fagus orientalis Lipsky.) forests. PhD Thesis. Graduate School of Natural and Applied Sciences. Istanbul, Turkey. Istanbul University. 360 p.

Cieszewski CJ. 2001. Three methods of deriving advanced dynamic site equations demonstrated on inland Douglas-Fir Site Curves. Canadian Journal of Forest Research 31: 165-173.

Curtis RO. 1982. A simple index of stand density for Douglas-fir. Forest Science 28(1): 92-94.

Davis PH. 1982. Flora of Turkey and the East Aegean Islands. 
Edinburgh, UK. Edinburgh University Press. 590 p.

Dittmar O, E Knapp, G Lembcke. 1986. DDR-Buchenertragstafel 1983. IFE-Berichte aus Forschung und Entwicklung 4: $1-59$.

Dmitriev IP. 1967. Yield advancing of beech stands of western USSR - Moscow. Forest industry. p. 203-205. (in Russian).

Ercanlı I, A Kahriman, H Yavuz. 2014. Dynamic base-age invariant site index models based on Generalized Algebraic Difference Approach for mixed Scotch Pine (Pinus sylvestris L.) and Oriental Beech (Fagus orientalis Lipsky) stands. Turkish Journal of Agriculture and Forestry 38 (1):134147.

Federal Agency of Forest Management of Russia. 2008. Tables and models of growth and productivity of forests of major forest forming species of Northern Eurasia. Second edition, supplemented. Moscow, Russia. Federal Agency of Forest Management of Russia. 883 p.

General Directorate of Forestry. 2015. Forets of Turkey. Ankara, Turkey. Turkey General Directorate of Forest Publications. $219 \mathrm{p}$.

Güvendi E. 2013. Determination of ecology based rotation length of naturally distributed pure Oriental Beech (Fagus Orientalis Lipsky.) stands (Example of Sinop-Ayanc1k-Türkeli). PhD Thesis. Trabzon, Turkey. Graduate School of Natural and Applied Sciences. Karadeniz Technical University.

Kalıpsız A. 1962. Growth and yield of Oriental Beech (Fagus Orientalis Lipsky.) stands. Publications of General Directorate of Forestry, Number 339. Istanbul, Turkey.

Marschall J. 1975. New yield tables for Austria. Allgemeine Forstzeitung 87(6):195-200.

Mendlik G. 1983. Beech yield table. Erdeszeti-Kutatasok 75:189198.

Pretzcsh H. 2009. Forest dynamics, growth and yield. Berlin, Germany. Springer International. 664 p.

Sagheb-Talebi K, Z Mirkazemi, R Akhavan, A Karimidoost, M Maghsoudloo, D Moghadasi. 2011. Some structural characteristics in the far east border of the distribution range of Oriental Beech (Fagus orientalis Lipsky) stands. In The 9th IUFRO International Beech Symposium. 12-17 September, Göttingen, Germany.

SPSS Institute Inc. 2010. IBM SPSS Statistics 19 Core System User's Guide. Chicago, UAS. SPSS. 426 p.

Vanclay JK. 1994. Modeling forest growth and yield. Applications to mixed tropical forests. Wallingford, UK. CABI Publishing. 312 p.

Weiskittel AR, DV Hann, JA Kershaw, JK Vanclay. 2011. Forest growth and yield modeling. Chicester, UK. Wiley - Blackweel. 430 p.

Recibido: 21.04 .16

Aceptado: 08.07.16 
